\title{
MISCONCEPTIONS OF GENETICS CONCEPTS AMONG PRE-SERVICE TEACHERS
}

\author{
A. BENJAMIN ETOBRO AND S. O. BANJOKO \\ (Received 14, August 2017; Revision Accepted 5, September 2017)
}

\begin{abstract}
Students' misconceptions are often deeply rooted and instruction-resistant obstacles to the acquizition of scientific concepts and remain even after instruction. A large number of prior studies reported that primary and secondary school students have many conceptional problems concerning cell biology and genetics. The study was set out to determine misconceptions held by pre-service teachers about genetics of Science and Technology Education Department at the Faculty of Education in Lagos State University. A sample of 120 pre-service biology teachers in their second and third year was purposively selected. Multiple-choice Genetic Concept Test (MGCT) and Pre-service Teachers' Genetics Misconceptions Checklist (PTMC) were administered to obtain information about pre-service teachers' understanding level of genetics. Results revealed that $75.1 \%$ on the average of pre-service teachers had misconceptions about genetics concepts. This percentage of pre-service teachers who have misconceptions could have been due to wrong understanding of the teachers to the concepts of genetics. Findings further showed that about $83.4 \%$ on the average of pre-service teachers attributed the misconceptions about genetics to challenges in genetics textbooks, instructional methods in teaching genetics, lecturers' English language skills, pre-service teachers' cultural beliefs and practices, nature of laboratories and abstractness of genetics. Science education and science teachers should take priority for the supplying of scientific literacy which is required for making informed decision about genetic related controversial issues imposed by daily life.
\end{abstract}

KEYWORDS: Genetics, Misconceptions, Pre-Service Teachers, Mendelian Inheritance, concepts

\section{INTRODUCTION}

Learning and students' performance in educational settings can be affected by diverse factors. These could be as a result of the following - school environment (physical structure, instructional media, auxiliary spaces, etc), teachers (qualification, teaching experience, teaching style, attitude, sympathy, language skill), students (i.e. their ability, intelligence quotient, learning styles, attitude, need, and motivational styles, epistemological beliefs, etc.), as well as assessment methods, and sociocultural factors (misconceptions, socio-economic status of parents/guardians). Misconception can be acquired by students prior to getting into school or it can be triggered at any stage of the formal education. Misconceptions refer to the concepts that have peculiar interpretations and meanings in students' perceptions that are not scientifically proven to be correct. Misconceptions have variously been referred to as naive beliefs, erroneous ideas, preconceptions and persistent pitfalls. However, prior to the formal education by learners at various levels, learners have brought incipient idea or concept about Biology. This initial idea brought in by students is sometimes contradictory and inappropriate to generally accepted idea or concept. These diverse concepts are often referred to as misconceptions or alternative concepts. They have their origin from learners' immediate environment, which are later taken to formal education starting at the primary level.

A. Benjamin Etobro, Department of Science and Technology Education, Faculty of Education, Lagos State University, Ojo, Nigeria.

S. O. Banjoko, Department of Science and Technology Education, Faculty of Education, Lagos State University, Ojo, Nigeria. 
Science seems to be a difficult subject to understand and comprehend. Regardless of age, culture, and education background, individual person has his/her own perception of science. Genetics is one of the difficult concepts in Biology because of its broad and complex nature. Genetics is the study of heredity, the process of transmitting certain genes from parents to offspring. Offspring inherit their biological parents' genes that express specific traits, such as some physical characteristics, natural talents, and genetic disorders. The mechanisms are hard to understand because it is difficult to make the ideas be tangible without the help of special instruments (Mbajiorgu, Ezechi and Idoko, 2006). The uses of the words genes, DNA, chromosomes, are interchanged in trying to explain how traits are passed from one generation to the next (Lewis and Kattmann, 2004). Mendelian Inheritance refers to the process of transmitting traits from one generation to another. The inherited traits are determined by genes that are passed from parents to offspring. An offspring inherits two sets of genes-one from each parent. A trait may not be observable, but its gene can be passed to the next generation. Students have an understanding on how genes play a role in transmitting traits, but this understanding is not aligned with the biological theory. Genes are passed down from parent as a whole and identically defines traits. Although this may be true based on observations, microscopically the mechanisms of genes and variations are more complex.

In Biology, misconceptions are commonly found among the concepts of respiration, ecology, genetics, photosynthesis, circulatory system, energy flow and classifications (Tekkaya, 2002). In recent years, misconceptions in science education have become a focal point of discussion by researchers. Recent studies have showed that learners had difficulty in understanding the science subjects and the difficulty of the students in these subjects created a significant challenge to learn the next level (Bahar, 2003). Misconception is also affected by all levels of learners, starting from the primary school to the university learners. Nadelson (2009) and Cokadar (2012) stressed that misconception is also prevalent to the teachers. Sources of these misconceptions may be due to the lack of proper application and use of media that cannot illustrate the concepts studied. More so, misconception perhaps is affected by the process of the formation of knowledge in the minds of students. According to Osokoya \& Etobro (2013), preservice teachers had misconceptions about global warming, greenhouse effect and ozone layer depletion due to their various scientific beliefs. Mustami (2016) reported that there are misconceptions in biology textbooks; thus, both teachers and students who use such textbooks will have misconceptions.

Students' misconceptions are often deeply rooted, instruction-resistant obstacles to the acquisition of scientific concepts and remain even after instruction. According to Dikmenli (2010), misconceptions are part of a larger knowledge system that involves many interrelated concepts that students use to make sense of their experiences. Students hold misconceptions that were developed before and during their early school years. One of the topics in biological field which become the research materials among educators is the difficulty of the students to understand the concept of genetics as well as the misconceptions on the connected materials (Mustami, 2016). A large number of prior studies reported that primary and secondary school students have many conceptional problems concerning cell biology and genetics (Flores et al., 2003; Lewis and Wood-Robinson, 2000; Marbach-Ad and Stavy, 2000, in Dikmenli, 2010).

However, there is dearth of literature on detailed research related to biology student teachers' misconceptions about cell. Dikmenli (2010) stressed that, prior studies have shown that students experience difficulties in learning concepts related to the cell division process. Cell division constitutes the basis for genetics, reproduction, growth, development, and molecular biology subjects in the biology curriculum. As a matter of fact, a majority of the students or teachers evaluated topics such as gene, DNA, chromosome, and cell division as difficult to learn topics (Oztas, Ozay and Oztas, 2003). Research on students' conceptual understandings often indicates that, even after being taught, students use misconceptions different from the scientific concepts (Lewis et al., 2000; Yesilyurt and Kara, 2007). Dikmenli (2010) adduced reasons for these misconceptions to include students' inability to differentiate between doubling (replication), pairing (synapsis), and separating (disjunction), as well as determining whether or not these processes occur in mitosis, meiosis, or both. Further misconceptions include a lack of understanding of basic terms confusing 
chromatids with chromosomes, or replicated chromosomes with un-replicated chromosomes. This is a concern for instructors because cell division processes are fundamental to the understanding of growth, development, reproduction, and genetics (Chinnici, Yue and Torres, 2004).

Dikmenli (2010) reported that studies conducted on problem-solving related to genetics revealed that students have some misconceptions regarding the stages of meiosis. However, accurate organization of many concepts in cell biology perhaps is dependent on the degree of understanding of cell division. Kibuka-Sebitosi (2007) stressed that students possess misconceptions and inadequate knowledge about the behavior of chromosomes and transference of genetic material during cell division. It further suggested that such misconceptions lead to conceptual problems in genetics. Saka, Cerrah, Akdeniz and Ayas (2006) have shown that science student teachers have misconceptions, particularly regarding the concepts of gene and chromosome, in accordance with their findings obtained from written responses and drawings.

Altunoğlu and Şeker (2015) emphasized that one of the most popular scientific and technological advances are related with genetics such as human genome project, genetically modified organism, cloning of organism, gene therapy and genetic background of various illness. In spite of the importance of these scientific and technological developments, there is dearth of public awareness of such progress. Thus, these advancements in genetics have caused serious concern to the society (Kilic \& Saglam 2014). For instance genetically modified organism have risks related with health problem and environmental problem but such organism can provide benefits; these controversial opinions were expressed by experts (Durrant \& Legge 2005). Altunoğlu and Şeker (2015) suggested that the society by such controversial topics needs basic knowledge to make meaningful decision which is the best one between lots of options. One paramount function of the teacher is the dissemination of information.

Misconceptions that already exist in students' minds are considered as barriers in understanding biological sciences, which may have adverse effect on subsequent learning. When students' initial understanding is not carefully considered, they may fail to grasp new concepts and information presented in the classroom, or they may learn for the purpose of test but revert to their misconceptions outside classroom (Ozmen, 2004). Recent studies on students' conceptual understanding of fundamental concepts in life science have indicated that new concepts can hardly be learned unless the existing misconception is corrected or students are made to bring conceptual change. However, before misconception can be corrected, they need to be identified. It is a well known fact that students enter into biology classroom with a lot of misconceptions which are based on their beliefs and observations. The study therefore, was set out to investigate existing misconceptions that conflict with currently accepted scientific concepts in studying about genetics of preservice teachers - undergraduates in their second and third year in the faculty of education. The study further identified sources of pre-service teachers' misconception and determined whether there was difference between the scores of preservice teachers' misconception in genetics based on year of study.

Two research questions and one hypothesis were answered and tested in the study.

\section{Research Questions}

1. What were the common misconceptions held by of pre-service teachers about genetics?

2. What were the sources of pre-service teachers' misconceptions about genetics?

\section{Hypothesis}

$\mathrm{H}_{0} 1$ : There is no significant difference between Multiple-choice Genetic Concept Test scores of pre-service teachers on misconceptions about genetics according to their year of study.

\section{Research Method}

Descriptive survey design was employed in this study. The sample of study consisted of 120 pre-service biology teachers in their second and third year of Science and Technology Education Department at the Faculty of Education in Lagos State University. A purposive sampling technique was employed in the selection of the respondents; since these were the students admitted to study Biology Education and would have taken some courses in genetics. 
Two research instruments were used in the collection of data - the Multiple-choice Genetic Concept Test (MGCT) and Pre-service Teachers' Genetics Misconceptions Checklist (PTMC); to obtain information about pre-service teachers' understanding level of genetics concepts such as DNA, chromosome, gene, genome and cell divisions. The multiple-choice Genetic Concept Test (MGCT) was developed by the researcher based on previously identified target concepts and propositional knowledge statements and from pre-service teachers' responses in an interview administered on some forth year pre-service teachers in the department. The MGCT consisted of 20 items. The PTMC was developed by the researcher. It consisted of nine broad areas that attracted a yes or no response.

The Multiple-choice Genetic Concept Test (MGCT) was developed by the researchers. The instrument was given to two lecturers of Faculty of Science, Lagos State University for its face and content validity. MGCT was administered on 20 undergraduates in their fourth year in Science and Technology Education
Department in order to determine its psychometric properties. After the pilot testing, twenty items were finally selected after the validation exercise. The result of the trial-out was analyzed using Kuder-Richardson formula (KR$20)$ to establish the reliability coefficient of the MGCT which gave a measure of .73.

Pre-service Teachers' Genetics Misconceptions Checklist (PTMC) was also developed by the researchers. The researchers in this study used the inter-rater reliability to establish the reliability estimate of the instrument. The scores of the raters were collated in order to estimate the inter-rater reliability using the Scott's (1955) coefficient formula also known as Scott's pie. The inter-rater reliability of the instrument yielded .79. The instruments were administered to the second and third year pre-service teachers. The data obtained were analyzed with frequency counts and the t-test.

\section{Research Question 1}

What were the common misconceptions held by pre-service teachers about genetics? 
Table 1: Common misconceptions of pre-service teachers about genetics

\begin{tabular}{|c|c|c|c|}
\hline $\mathbf{S} / \mathbf{N}$ & $\begin{array}{l}\text { Categories of } \\
\text { misconceptions }\end{array}$ & Types of misconceptions & $\begin{array}{l}\% \text { of Pre-service } \\
\text { teachers with } \\
\text { misconceptions }\end{array}$ \\
\hline 1 & \multirow{7}{*}{ Cell Division } & & \\
\hline & & Diploid $(2 n)$ cells are formed as a result of meiosis. & 84 \\
\hline 2 & & Centrioles are found in the nucleus of a cell. & 82 \\
\hline 3 & & $\begin{array}{l}\text { Meiosis occurs in the reproductive (sperm or egg) } \\
\text { cells. }\end{array}$ & 76 \\
\hline 4 & & $\begin{array}{l}\text { The centrosome and centrioles is essentially the } \\
\text { same thing. }\end{array}$ & 70 \\
\hline 5 & & $\begin{array}{l}\text { Crossing over occurs at the metaphase-I of the } \\
\text { meiosis. }\end{array}$ & 67 \\
\hline 6 & & Diploid $(2 n)$ cells are formed as a result of meiosis. & 76 \\
\hline 7 & \multirow{3}{*}{ Chromosome } & $\begin{array}{l}\text { Chromosomes are formed as a result of shrinkage } \\
\text { and thickening of spindle fibers. }\end{array}$ & 81 \\
\hline 8 & & $\begin{array}{l}\text { Future knowledge about genetics could help stop } \\
\text { deadly diseases and cancers }\end{array}$ & 76 \\
\hline 9 & & All diseases are contagious & 66 \\
\hline 10 & \multirow{4}{*}{ DNA } & $\begin{array}{l}\text { All humans have DNA, as do animals, plants, and } \\
\text { most bacteria and fungi. }\end{array}$ & 88 \\
\hline 11 & & $\begin{array}{l}\text { DNA replication takes place only in the meiosis } \\
\text { process. }\end{array}$ & 78 \\
\hline 12 & & $\begin{array}{l}\text { Half of an offspring DNA is determined by maternal } \\
\text { side, and half is by the paternal side. }\end{array}$ & 76 \\
\hline 13 & & $\begin{array}{l}\text { DNA replication occurs in cytokinesis during the } \\
\text { process of cell division. }\end{array}$ & 72 \\
\hline 14 & \multirow{4}{*}{ Gene } & Genes determine everything from our sex & 77 \\
\hline 15 & & $\begin{array}{l}\text { There is a conception of genes not only } \\
\text { determining traits }\end{array}$ & 76 \\
\hline 16 & & Genetic drift only occurs in small populations. & 63 \\
\hline 17 & & All cells have nuclei. & 64 \\
\hline 18 & \multirow{3}{*}{$\begin{array}{l}\text { Mendelian } \\
\text { Inheritance }\end{array}$} & $\begin{array}{l}\text { Dominant alleles will take over a population and } \\
\text { create the prominent phenotype }\end{array}$ & 79 \\
\hline 19 & & $\begin{array}{l}\text { If all members on both sides of a family is tall, the } \\
\text { offspring are going to be tall }\end{array}$ & 72 \\
\hline 20 & & $\begin{array}{l}\text { Deleterious alleles will go into extinction because } \\
\text { of the present of dominant alleles }\end{array}$ & 79 \\
\hline
\end{tabular}

Table 1 showed the percentage of preservice teachers' common misconceptions concepts in genetics based on the analysis of
Multiple Choice Genetic Concept Test (MGCT). The table also revealed 20 types of common misconceptions about genetics. The 
misconceptions were grouped into the five categories: cell division, chromosome, DNA, gene and Mendelian inheritance. The results revealed that $75.1 \%$ on the average of preservice teachers had misconceptions about genetics concepts. Table 1 also showed the five categories of genetics misconceptions. DNA has the highest $(78.5 \%)$ number of pre-service teachers with misconceptions. This is followed by Mendelian inheritance with $76.67 \%$ of the pre- service teachers with misconceptions, while the third misconception is in the cell division $75.8 \%$. Furthermore, $74.3 \%$ of the pre-service teachers have misconceptions with chromosome. Finally, $70 \%$ of the pre-service teachers have misconceptions with gene.

\section{Research Question 2}

What were the sources of pre-service teachers' misconceptions about genetics?

Table 1: Sources of pre-service teachers' misconceptions about genetics

\begin{tabular}{|c|c|c|c|c|c|}
\hline $\mathbf{S} / \mathbf{N}$ & $\begin{array}{l}\text { Major source of pre-service teachers' } \\
\text { misconception }\end{array}$ & $\begin{array}{l}\text { Responses } \\
200 \mathrm{~L} \\
\text { Yes f (\%) }\end{array}$ & No f (\%) & $\begin{array}{l}300 \mathrm{~L} \\
\text { Yes f (\%) }\end{array}$ & No f (\%) \\
\hline 1 & Genetics textbooks & $107(89.17)$ & $13(10.83)$ & $92(76.67)$ & $28(23.33)$ \\
\hline 2 & Genetics teachers' guide & $57(47.5)$ & $63(52.5)$ & $34(28.33)$ & $86(71.67)$ \\
\hline 3 & Genetics reference books & $23(19.17)$ & $97(80.83$ & $34(28.33)$ & $86(71.67)$ \\
\hline 4 & $\begin{array}{l}\text { Instructional methods in teaching } \\
\text { Genetics }\end{array}$ & $112(93.33)$ & $8(6.67)$ & $102(85)$ & $18(15)$ \\
\hline 5 & Lecturers' English language skills & $105(87.5)$ & $15(12.5)$ & $99(82.5)$ & $21(17.5)$ \\
\hline 6 & $\begin{array}{l}\text { Pre-service teachers' cultural beliefs } \\
\text { and practices }\end{array}$ & $87(72.5)$ & $33(27.5)$ & $75(62.5)$ & $45(37.5)$ \\
\hline 7 & $\begin{array}{l}\text { Lecturers' competency of subject } \\
\text { matter }\end{array}$ & $27(22.5)$ & $93(77.5)$ & $36(30)$ & $84(70)$ \\
\hline 8 & Nature of laboratories & $109(90.83)$ & $11(9.17)$ & $99(82.5)$ & $21(17.5)$ \\
\hline 9 & Abstractness of Genetics & $112(93.33)$ & $8(6.67)$ & $102(85)$ & $18(15)$ \\
\hline
\end{tabular}

Table 2 showed data on pre-service teachers' misconception about genetics. Their responses were collected through close-ended questionnaires described by means of two categories that was either yes or no. Table 2 revealed that about $83.4 \%$ on the average of preservice teachers in items $1,4,5,6,8$ and 9 responded that the major sources of students' misconceptions about genetics for both second and third year pre-service teachers were attributed to challenges in genetics textbooks, instructional methods in teaching genetics, lecturers' English language skills, pre-service teachers' cultural beliefs and practices, nature of laboratories and abstractness of genetics. The table also revealed that few pre-service teachers attributed the sources of students' misconceptions to genetics teachers' guide, genetics reference books and lecturers' competency of subject matter.

\section{Hypothesis testing}

$\mathrm{H}_{0} 1$ : There is no significant difference between Multiple-choice Genetic Concept Test scores of pre-service teachers on misconceptions about genetics according to their year of study.

Table 3: t-test on the pre-service teachers' sources of misconceptions based on their year of study

\begin{tabular}{lllllcc}
\hline Level & $\mathbf{N}$ & Mean & SD & df & Sig. (2-tailed) & t-value \\
\hline $2^{\text {nd }}$ Year & 68 & 7.77 & 1.975 & \multirow{2}{*}{118} & .216 & \multirow{2}{*}{1.244} \\
$3^{\text {rd }}$ Year & 52 & 7.09 & 1.971 & & & \\
\hline
\end{tabular}


Table 3 showed that there is no significant difference between MGCT scores of pre-service teachers on misconceptions about genetics according to their year of study ( $\mathrm{t}=$ $1.244, \mathrm{df}=118, \mathrm{p}=.216)$. Hence, the hypothesis which states that there is no statistically significant difference between MGCT scores of pre-service teachers on misconceptions about genetics according to their year of study is not rejected at .05 significant level.

\section{Discussion}

The origins of the misconceptions perhaps result from teaching and textbooks. Most textbooks begin with simple Mendelian genetics, which usually show dominant alleles as being more powerful and overshadowing recessive alleles in the heterozygous form. This is thereafter followed with the discussion on Mendelian genetics; textbooks will explain situations such as incomplete dominance, codominance, multiple alleles and gene linkage that also appear in genetics problems. However, the emphasis in the textbooks and teaching is on Mendelian genetics, which could cause the students to believe dominant alleles are more prevalent in a population and will be more frequent than recessive alleles, especially because the dominant phenotype appears in both the homozygous dominant condition and the heterozygous condition whereas the recessive phenotype only appears in the homozygous recessive condition.

The results revealed that $75.1 \%$ on the average, of pre-service teachers had misconceptions about genetics concepts. This percentage of pre-service teachers who have misconceptions could have been due to wrong understanding of the teachers to the concepts of genetics. This finding is in agreement with Mustami (2016) who attributed this wrong understanding to the incompleteness of information students received from their learning experiences and from their peers. This naïve experience of the pre-service teachers could have influenced the misconceptions that were observed in genetics concepts.

In addition to these conceptual and procedural difficulties in genetics learning, preservice teachers attributed misconceptions in genetics to the challenges in genetics textbooks, instructional methods in teaching genetics, lecturers' English language skills, pre-service teachers' cultural beliefs and practices, nature of laboratories and abstractness of genetics.
Duncan and Reiser (2007) stated that students have learning difficulties in genetics concepts because these micro-level concepts are invisible and inaccessible. Kılıç, Atav, Sağlam (2006) suggested that if the concepts related to somatic and sex cells is taught first, in future the learning of these concepts will construct a basis to learn genetics concepts more easily.

\section{CONCLUSION}

Findings in this study showed that majority of pre-service teachers had misconceptions in genetics. A high percentage of pre-service teachers experiencing misconceptions in genetics were observed in all the sub-categories tested. DNA sub-category has the highest number of pre-service teachers with misconceptions. This is followed by Mendelian inheritance, while the third misconception is in the cell division sub-category. Finally, the least subcategory where pre-service teachers had misconceptions was the gene, implying that pre-service teachers did not have much difficulty in the concept of genes. The factors causing misconceptions include challenges in genetics textbooks, instructional methods in teaching genetics, lecturers' English language skills, pre-service teachers' cultural beliefs and practices, nature of laboratories and abstractness of genetics. However, few preservice teachers attributed the sources of students' misconceptions to genetics lecturers' guide, genetics reference books and lecturers' competency of subject matter; although there was no significant difference in the misconceptions about genetics of pre-service teachers on the basis of their year of study. There is need to make genetics courses more contemporary by exploring hands-on and mindson activities that are pragmatic. Such genetics courses should be supported by quality textbooks, instructional methods, lecturers' guide and carrying out experiments that would actively engage students in learning processes.

\section{REFERENCES}

Altunoglu, B. D and Seker, M., 2015. The Understandings of Genetics Concepts and Learning Approach of Pre-Service Science Teachers. Journal of Educational and Social Research MCSER Publishing, Rome-Italy. 5, (1): S1 
Bahar, M., Ozel, M., Prokop, P and Usak, M., 2008. Science student-teachers" ideas of the heart. Journal of baltic science education. $7,(2):$ 78-85.

Chinnici, J. P, Yue, J. W and Torres, K. M., 2004. Student as "human chromosomes" in role-playing mitosis and meiosis. The Am. Bio. Teach. 66(1): 35-39.

Cokadar, H., 2012. Photosynthesis and respiration processes: Prospective teachers conception levels. Educ. Sci., 37: 81-93.

Durant, R. F and Legge, J. S., 2005. Public Opinion, Risk Perceptions, and Genetically Modified Food Regulatory Policy Reassessing the Calculus of Dissent among European Citizens. European Union Politics, 6(2), 181-200.

Flores, F., Tovar, M and Gallegos, L., 2003. Representation of the cell and its processes in high school students: An integrated view. International Journal of Science Education 25(2): 269-286.

Kibuka-Sebitosi, E., 2007. Understanding genetics and inheritance in rural schools. J. Bio. Edu. 41(2): 56-61.

Lewis, J and Kattmann, U., 2004. Traits, genes, particles and information: re-visiting students' understanding of genetics. International Journal of Science Education, 26, 195-206.

Lewis, J., Leach, J and Wood-Robinson, C., 2000. Chromosomes the missing link- young people understands of mitosis, meiosis, and fertilization. Journal of biological education. 34(4): 189-200.

Marbach-Ad, G and Stavy, R., 2000. Students cellular and molecular explanations of genetic phenomena. Journal Biology Education. 34, (4): 200-205.

Mbajiorgu, N., Ezechi, N and Idoko, C., 2006. Addressing nonscientific presuppositions in genetics using a conceptual change strategy. Science Education, 419-438.
Mustami M. K., 2016. Identifying the Misconception in Students' Biology Department on Genetics Concept with CRI Method. The Social Sciences 11 (13): 3348-3351.

Nadelson, L. S., 2009. Preservice teacher understanding and vision of how to teach biological evolution. Evol. Educ. Outreach, 2: 490-504.

Osokoya, M. M and Etobro, A. B., 2013. Perception of Pre-Service Science Teachers about Global Warming and Greenhouse Effect on Ozone Layer. Education and the transformation agenda of nations: Hindsight, insight and foresight. Conference Proceedings. Lagos. Pp 229-239.

Ozmen, H., 2004. Some Student Misconceptions in Chemistry: A Literature Review of Chemical Bonding. Journal of Science Education and Technology.13 (2): 147159.

Oztas, H., Ozay, E and Oztas, F., 2003. Teaching cell division to secondary school students: An investigation of difficulties experienced by Turkish teachers. Journal Biology Education. 38, (1): 13-15.

Saka, A., Cerrah, L., Akdeniz, A. R and Ayas, A., 2006. A cross-age study of the understanding of three genetic concepts: How do they image the gene, DNA and chromosome? Journal Science Education Technology. 15, (2): 192-202.

Scott, J., 1969. Corruption, machine politics, and political change. American Political Science Review 63(4), 1142-1158.

Tekkaya, C., 2002. Misconceptions as barrier to understanding biology. Journal Science Education. 23: 259-266.

Yesilyurt, S and Kara, Y., 2007. The effects of tutorial and edutainment software programs on students' achievements, misconceptions and attitudes towards biology on the cell division issue. J. Baltic Sci. Edu. 6, (2): 5-15. 
